\title{
Pengaruh Pendidikan Gizi terhadap Pengetahuan, Sikap, dan Keterampilan Kader Melakukan Konseling Gizi di Posyandu
}

\section{The Effect of Nutrition Education in Cadre Knowledge, Attitude, and Skills of Nutrition Counselling in Integrated Service Post (Posyandu)}

Adillah Imansari ${ }^{1}$, Siti Madanijah ${ }^{1}$, Lilik Kustiyah ${ }^{1}$

\begin{abstract}
ABSTRAK
Latar Belakang: Kegiatan kader melakukan konseling di posyandu dalam pelaksanaannya belum berjalan dengan maksimal. Hal ini karena dipengaruhi oleh pengetahuan dan keterampilan kader yang belum memadai.

Tujuan: Mendiskripsikan dan menganalisis pemberian pendidikan gizi terhadap pengetahuan, sikap dan keterampilan konseling gizi di posyandu.

Metode: Desain penelitian ini menggunakan non-randomized pretest-posttest control group. Subjek penelitian berjumlah 60 kader dari Kecamatan Tatanga, Kota Palu yang dibagi menjadi 2 kelompok yaitu kelompok intervensi dan kontrol. Penelitian ini dilaksanakan pada bulan Juni -Agustus 2019. Kelompok intervensi diberikan pendidikan gizi dengan metode simuasi dan teknik menggunakan media modul dan kelompok kontrol diberikan pendidikan gizi dengan metode ceramah tanpa modul. Analisis data berupa analisis deskriptif dan bivariat.

Hasil: Hasil penelitian sebelum intervensi (pre-test) menunjukkan karakteristik (umur, pendidikan, pekerjaan, lama menjadi kader dan frekuensi mengikuti pelatihan), skor pengetahuan, skor sikap dan skor keterampilan konseling tidak berbeda signifikan antara kelompok intervensi dan kontrol. Hasil setelah intervensi (post-test) menunjukkan terdapat perbedaan signifikan skor pengetahuan, sikap dan keterampilan konseling pada kelompok intervensi yang cenderung lebih tinggi dibandingkan kontrol.

Kesimpulan: Pendidikan gizi berpengaruh signifikan pada nilai pengetahuan, sikap dan keterampilan konseling pada kelompok intervensi yang cenderung lebih baik dariapda kelompok kontrol. Metode simulasi dan praktik merupakan metode yang efektif pada pengetahuan, sikap dan keterampilan kader dalam melakukan konseling di posyandu.
\end{abstract}

Kata kunci: Kader, Konseling Gizi, Pendidikan Gizi, Posyandu

\section{ABSTRACT}

Background: Cadre activities at Posyandu in its implementation have not been running optimally. This ini because it requires inadequate knowledge and skills of cadres.

Objectives: to describe and analyze the effect of nutrition education in cadre's knowledge, attitudes, and skills of nutrition counseling at posyandu

Methods: The design of this study used non-randomized pretest-posttest control group. The research subjects consisted of 60 cadres Tatanga District, Palu City which was divided into 2 groups, were the intervention and control groups. This research was conducted in June until August 2019. The intervention group was given nutrition education with simulation and practice using modules and the control group was given nutrition education without modules. Data analysis used descriptive and bivariate analysis.

Results: The result of pre-test showed characteristic (age, education, occupation, length of time for cadres and frequency of training), knowledge, attitude and counseling skills scores did not differ significantly between the intervention and control group. The result of post-test showed a significant difference between knowledge, attitude and counseling skills in the intervention group that was higher than the control.

Conclusions: Nutrition education is important in the value of knowledge, attitudes, and counseling skills in the group better than the control group. Simulation and practice methods are effective methods for cadre knowledge, attitude, skills in counselling at posyandu.

Keywords: Cadres, Nutrition Counselling, Nutrition Education, Posyandu

\author{
*Korespondensi: \\ imansari.adillah@gmail.com* \\ Adillah Imansari \\ 1Departemen Gizi, Fakultas Ekologi Manusia, Institut Pertanian Bogor, Indonesia
}




\section{PENDAHULUAN}

Masalah gizi kronis pada usia balita (bayi di bawah lima tahun) memiliki dampak jangka panjang terhadap kualitas sumber daya manusia ${ }^{1}$. Berdasarkan data Kementerian kesehatan (Kemenkes) dalam hasil Riset Kesehatan Dasar (Riskesdas 2018) di Indonesia menunjukkan bahwa prevalensi status gizi buruk balita sebesar $3.9 \%$, gizi kurang sebesar $17.7 \%$ dan stunting sebesar $29.9 \%^{2}$. Sementara itu, data Kemenkes dalam hasil pemantauan status gizi (PGS 2017) menunjukkan bahwa prevalensi gizi buruk balita sebesar $12.5 \%$, gizi kurang sebesar $24.1 \%$ dan stunting sebesar $36.8 \%^{3}$.

Berbagai upaya pencegahan telah dilakukan salah satunya adalah pembangunan kesehatan dalam periode 2015-2019 yang berfokus pada peningkatan pelayanan kesehatan masyarakat yaitu meningkatkan status gizi masyarakat, khususnya status gizi pada balita ${ }^{4}$. Salah satu pelayanan kesehatan berbasis masyarakat yang salah satunya berfokus dalam mendeteksi dan meningkatkan status gizi balita adalah Pos pelayanan terpadu ${ }^{5}$. Keberhasilan kegiatan posyandu tidak lepas dari peran aktif kader sebagai pendorong proses perubahan di masyarakat dan sebagai penghubung serta fasilitas yang mendukung dalam melaksanakan kegiatan Posyandu ${ }^{67}$. Kegiatan tersebut dikenal dengan istilah lima meja (pendaftaran, penimbangan, pencatatan, konseling dan pelayanan kesehatan). Namun dalam pelaksanaannya, kader tidak maksimal melaksanakan kegiatan posyandu yaitu konseling gizi ${ }^{7}$.

Penelitian Rahmawati pada kader di Kecamatan Ciomas kota Bogor menyebutkan bahwa konseling gizi jarang dilakukan kader disebabkan oleh kondisi di lapangan seperti keterbatasan waktu dan fasilitas (alat bantu media konseling dan pengukuran panjang badan) serta kader belum memiliki keberanian dan keterampilan yang memadai ${ }^{8}$. Kualitas sumber daya kader yang masih kurang dapat disebabkan oleh pengetahuan dan keterampilan kader yang belum memadai untuk melakukan konseling gizi di posyandu ${ }^{9}$. Selain itu, tidak ada pedoman pelatihan dalam manajemen pelatihan kader dan perencanaan pelatihan tidak melibatkan kader sehingga pelaksanaan pelatihan tidak sesuai dengan tujuan pelatihan kader dan evaluasi tidak dilakukan setelah pelatihan ${ }^{10}$.

Pendidikan gizi merupakan kombinasi strategi terencana yang betujuan untuk meningkatkan pengetahuan, sikap dan perubahan perilaku ${ }^{11}$. Sementara itu, metode pelatihan yang efektif adalah metode yang tidak hanya ceramah namun disertai dengan simulasi, praktik dan diikuti studi kasus sehingga akan mempermudah penyampaian informasi, pemahaman dan keterampilan ${ }^{12,13}$. Berdasarkan pemaparan masalah ini, tujuan dari penelitian ini adalah untuk menganalisis pengaruh pendidikan gizi terhadap pengetahuan, sikap dan keterampilan kader dalam melaksanakan kegiatan konseling gizi di posyandu.

\section{METODE}

Penelitian ini menggunakan desain quasiexperiment dengan rancangan non-randomized control group pre-post-test. Penelitian ini dilaksanakan bulan Juni sampai Agustus 2019. Penelitian dilakukan di Kecamatan Tatanga, Kota Palu, Sulawesi Tengah.
Penentuan lokasi penelitian dilakukan secara purposif berdasarkan karakteristik wilayah yang memiliki kader yang aktif namun kegiatan konseling gizi di posyandu belum berjalan, serta kesediaan wilayah puskesmas dijadikan tempat penelitian. Penelitian ini telah mendapatkan persetujuan dari komisi etik penelitian yang melibatkan subyek manusia Institut Pertanian Bogor (IPB) dengan nomor 136/IT3.KEPMSM-IPB/SK/2018.

Subjek penelitian ini adalah seluruh kader di Kecamatan Tatanga, Kota Palu, Sulawesi Tengah. Sampel dalam penelitian ini adalah seluruh kader dalam kategori posyandu madya yaitu posyandu yang memiliki kader beranggotakan 5 orang serta melalui kriteria inklusi dan eksklusi. Kriteria inklusi meliputi kader yang terdaftar di Kecamatan Tatanga, bisa membaca dan menulis, bersedia mengisi informed consent dan mengikuti seluruh kegiatan intervensi. Kriteria eksklusi meliputi kader dalam waktu 6 bulan terakhir tidak aktif dalam kegaitan posyandu. Perhitungan sampel menggunakan uji hipotesis beda proporsi dua populasi dengan mengacu pada hasil penelitian Rahmawati tahun 2019 yang menghasilkan minimal 28 subjek setiap kelompok. Jumlah subjek yang dikumpulkan sebanyak 60 subjek yang dibagi dalam 2 kelompok yaitu kelompok intervensi dan kontrol ${ }^{8}$.

Data karakteristik kader (umur, pendidikan, pekerjaan kader, lama menjadi kader dan pernah tidaknya mengikuti pelatihan) dikumpulkan dengan cara pengisian kuesioner. Data pengetahuan kader diperoleh dengan cara pengisian kuesioner berisi pertanyaan tentang status gizi (stunting), ASI (Air Susu lbu) Eksklusif, MP-ASI (Makanan Pendamping Air Susu Ibu), pemantauan pertumbuhan dan konseling gizi dengan jumlah 17 soal dalam bentuk pilihan ganda. Data sikap diperoleh dengan cara pengisian kuesioner 10 pernyataan sikap positif tentang ASI, MP-ASI, pemantauan pertumbuhan dan konseling gizi. Data keterampilan konseling diperoleh dengan cara pengisian lembar penilaian observasi yang diisi oleh peneliti. Lembar penilaian terdiri dari 12 indikator tentang keterampilan konseling gizi yang merupakan hasil modifikasi dari penelitian Rahmawati $^{8}$. Uji validitas dan reliabilitas dilakukan pada 30 orang kader posyandu di wilayah kerja puskesmas Nosarara Palu. Hasil uji untuk kuesioner pengetahuan (nilai Cronbach's Alpha 0.68), sikap (nilai Cronbach's Alpha 0.633), keterampilan konseling gizi (nilai Cronbach's Alpha 0.628), sehingga diperoleh nilai Cronbach's Alpha $>0.6$ yang menyatakan item pertanyaan reliabel.

Pengambilan data pre-test (pengetahuan, sikap dan keterampilan) dilakukan sebelum pelatihan kader. Kelompok intervensi diberikan pendidikan gizi sebanyak 3 kali pertemuan. Pertemuan pertama dilakukan di Aula Puskesmas Nosarara dengan durasi 5 jam. Materi pelatihan tentang masalah gizi pada balita (stunting), ASI Eksklusif, MP-ASI dan Perilaku Hidup Bersih dan Sehat (PHBS) dengan metode ceramah, tanya jawab dan diskusi. Pertemuan kedua dan ketiga dilaksanakan di posyandu dengan durasi 2-3 jam dengan metode simulasi dan praktik. Materi pertemuan kedua tentang pemantauan pertumbuhan (cara penimbangan dan pengukuran tinggi badan dengan benar) dan konseling gizi (menjelaskan hasil penimbang KMS (Kartu Menuju Sehat) dan cara melakukan konseling dengan benar). Sementara itu, 
pertemuan ketiga adalah pendalaman materi pertemuan sebelumnya. Media yang digunakan adalah power point, modul dan lembar balik yang dimodifikasi dari buku KIA (Kesehatan Ibu Anak) ${ }^{14}$. Pada kelompok kontrol diberikan pendidikan gizi sebanyak 1 kali pertemuan dengan materi tentang ASI Eksklusif, MP-ASI dan PHBS. Pelatihan dilakukan di aula puskesmas dengan durasi 2 jam. Materi diberikan dengan metode ceramah dan tanya jawab. Media yang digunakan adalah power point tanpa modul. Setelah intervensi, dilakukan post-test pengetahuan dan sikap setelah pelatihan dilakukan dan keterampilan saat hari $\mathrm{H}$ posyandu setelah pelatihan. Kemudian pengumpulan data post-test ke-2 (pengetahuan, sikap dan keterampilan) yang dilakukan sebulan setelah pelatihan.

Pengolahan dan analisis data dilakukan dengan menggunakan Microsoft Excel 2013 dan SPSS versi 16.0. Pengetahuan kader, jika menjawab benar bernilai 1 dan salah bernilai 0 . Sikap kader berdasarkan skala likert yaitu 1
= sangat tidak setuju, 2 = tidak setuju, 3 = ragu-ragu, $4=$ setuju dan 5 = sangat setuju. Keterampilan kader melakukan konseling gizi, jika melakukan setiap indikator konseling dengan benar masing-masing bernilai 1 dan salah bernila 0 . Kategori untuk variabel pengetahuan dan sikap dikatakan kurang apabila $<60$, cukup 60-79 dan baik $\geq 80$. Sementara variabel keterampian dikatakan kurang bila nilai $<50$, cukup $50-85$ dan baik bila nilai $>85^{8}$. Analisis variabel meliputi analisis deskripsif (rataan $\pm S D$, persentase), uji normalitas, dan uji beda. Uji t berpasangan (uji Wilcoxon jika hasil uji normalitas tidak terdistribusi normal) digunakan untuk menganalisis pengaruh pendidikan gizi terhadap pengetahuan, sikap dan keterampilan konseling gizi sebelum dan setelah intervensi. Uji t independen (uji Mann Whitney jika hasil uji normalitas tidak terdistribusi normal) digunakan untuk menganalisis pengaruh pendidikan gizi pengetahuan, sikap dan keterampilan konseling gizi sebelum dan setelah perlakuan pada masingmasing kelompok.

\section{HASIL DAN PEMBAHASAN}

Tabel 1 Karakteristik Kader(Umur, Pendidikan, Pekerjaan, Lama menjadi Kader dan Frekuensi mengikuti Pelatihan) di Kecamatan Tatanga Tahun 2019

\begin{tabular}{|c|c|c|c|}
\hline \multirow[t]{2}{*}{ Karakteristik kader } & Intervensi & Kontrol & \multirow{2}{*}{$\mu$ value } \\
\hline & \multicolumn{2}{|c|}{$\overline{\mathrm{n}(\%)}$} & \\
\hline Umur (tahun) & & & $0.377^{1}$ \\
\hline$<35$ & $10(33.3)$ & $6(20.0)$ & \\
\hline $35-45$ & $14(46.7)$ & $18(60.0)$ & \\
\hline$>45$ & $6(20.0)$ & $6(20.0)$ & \\
\hline Pendidikan & & & $0.72^{1}$ \\
\hline$\leq$ tamat SMP & $4(13.3)$ & $5(16.7)$ & \\
\hline Tamat SMA & $26(86.7)$ & $25(83.3)$ & \\
\hline \multicolumn{4}{|l|}{ Pekerjaan } \\
\hline Ibu rumah tangga (IRT) & $23(76.7)$ & $24(80.0)$ & $0.756^{1}$ \\
\hline Wiraswasta & $7(23.3)$ & $6(20.0)$ & \\
\hline Lama menjadi kader (tahun) & & & $0.835^{1}$ \\
\hline$<5$ & $12(40.0)$ & $9(30.0)$ & \\
\hline $5-10$ & $10(33.3)$ & $14(46.7)$ & \\
\hline$>10$ & $8(26.7)$ & $7(23.3)$ & \\
\hline \multirow{2}{*}{\multicolumn{4}{|c|}{$\begin{array}{l}\text { Frekuensi mengikuti pelatihan } \\
\text { ( } 3 \text { tahun terakhir) }\end{array}$}} \\
\hline & & & \\
\hline Tidak pernah & $3(10.0)$ & $5(16.7)$ & $0.521^{1}$ \\
\hline 1 kali & $5(16.7)$ & $5(16.7)$ & \\
\hline$\geq 2$ kali & $22(73.3)$ & $20(66.7)$ & \\
\hline
\end{tabular}

1Uji Mann Whitney, signifikan bila $p<0.05$

Berdasarkan Tabel 1, karakteristik umum subjek (umur, pendidikan, pekerjaan, lama menjadi kader dan frekuensi mengikuti pelatihan) tidak berbeda secara signifikan, sehingga perubahan hasil intervensi diindikasikan merupakan pengaruh dari intervensi bukan karakteristik subjek. Jumlah kader sebagai subjek pada dua kelompok sebanyak 60 orang.

Rata-rata umur subjek adalah 40 tahun dengan persentasi subjek terbesar berusia antara 35-45 tahun yaitu $46.7 \%$ pada kelompok intervensi dan $60 \%$ pada kelompok kontrol. Umur antara 20-40 tahun merupakan umur produktif yang memiliki kemampuan yang matang untuk berpikir dan bekerja ${ }^{15}$. Pendidikan dan pekerjaan kedua kelompok hampir sama. Sebagian besar (lebih dari $80 \%)$ kader mempunyai pendidikan terakhir setingkat SMA. Pekerjaan kader pada umumnya sebagai ibu rumah
${ }^{2}$ Uji Wilcoxon, signifikan bila $\mathrm{p}<0.05$

tangga, hanya sekitar 20-23\% kader sebagai wiraswasta. Kader yang memiliki pendidikan terakhir SMA dapat lebih mudah menerima dan memahami informasi yang diberikan ${ }^{16}$. Selain itu, kader yang berkerja sebagai ibu rumah tangga tanpa pekerjaan tambahan memiliki waktu yang lebih banyak untuk fokus dengan tugas dan tanggungjawabnya sebagai kader di posyandu ${ }^{17,18}$.

Rata-rata subjek bertugas sebagai kader sudah cukup lama yaitu 7 tahun, di mana sebanyak $56.7 \%$ dan $60 \%$ kader pada kelompok intervensi dan kontrol telah bertugas lebih dari lima tahun. Kemudian, dengan masa kerja yang cukup lama, sekitar $70 \%$ kader telah pernah mengikuti pelatihan $\geq 2$ kali. Frekuensi pelatihan kader yang telah diikuti, dapat meningkatkan keterampilan kader dalam menjalankan tugasnya di posyandu ${ }^{19}$. 
Tabel 2 Rerata skor pengetahuan kader pada kelompok intervensi dan kontrol

\begin{tabular}{|c|c|c|c|}
\hline \multirow[t]{2}{*}{ Pengetahuan } & Intervensi & Kontrol & \multirow[t]{2}{*}{$\mathrm{p}$ value } \\
\hline & \multicolumn{2}{|c|}{ n (\%) } & \\
\hline Pre-test (rataan $\pm \mathrm{SD})$ & $67.64 \pm 14.7$ & $63.53 \pm 15.16$ & $0.292^{3}$ \\
\hline Post-test (rataan $\pm \mathrm{SD})$ & $89.60 \pm 9.73$ & $74.70 \pm 12.56$ & $0.002^{3}$ \\
\hline Post-test 2 (rataan \pm SD) & $90 \pm 8.34$ & $83.33 \pm 6.38$ & $0.001^{3}$ \\
\hline Selisih (Post-test 1 - Pre-test) & 21.96 & 11.17 & $0.002^{3}$ \\
\hline p value & $0.001^{4}$ & $0.001^{4}$ & \\
\hline Selisih (Post-test 2 - Post test 1 ) & 0.4 & 8.63 & $0.004^{3}$ \\
\hline $\mathrm{p}$ value & $0.763^{4}$ & $0.001^{4}$ & \\
\hline
\end{tabular}

${ }^{3}$ Uji t independen, signifikan bila $p<0.05$

Hasil pre-test pada Tabel 2 menunjukkan bahwa nilai pengetahuan antara kelompok intervensi dan kontrol tidak ada perbedaan yang signifikan ( $p>0.05)$. Namun, setelah intervensi di lakukan (post-test 1) dan sebulan setelah intervensi (post-test 2) menunjukkan terdapat perbedaan yang signifikan dari nilai pengetahuan antara kelompok intervensi dan kontrol. Hasil penelitian ini serupa dengan penelitian Rahmawati yang menunjukkan terjadi peningkatan nilai pengetahuan kader setelah diberikan pendidikan gizi pada kelompok intervensi dan kontrol. Namun dengan teknik simulasi

dan praktik mampu meningkatkan skor pengetahuan kader lebih tinggi dibandingkan kelompok kontrol yang hanya diberikan pendidikan gizi dengan teknik ceramah ${ }^{8}$. Berdasarkan selisih nilai pengetahuan antara sebelum dan setelah intervensi diketahui bahwa pendidikan gizi secara signifikan dapat meningkatkan nilai pengetahuan sebesar 21.96 poin pada kelompok intervensi dan 11.17 poin pada kelompok kontrol. Selain itu, selisih antara post-test 1 dan post-test 2 pada kelompok intervensi terdapat peningkatan nilai pengetahuan (0.4 poin), namun tidak berbeda signifikan. Sedangkan pada kelompok kontrol terdapat peningkatan nilai pengetahuan (8.63 poin) yang berbeda secara signifikan. Hasil nilai pengetahuan pada kelompok intervensi yang tidak berbeda signifikan dan cenderung lebih rendah dibandingkan kelompok kontrol diduga karena sebagian besar (90\%) kader memiliki pengetahuan yang baik, sehingga hasil post-test 2 tidak mengalami perbedaan yang signifikan. Hal ini sejalan dengan penelitian Anani dan Mahmudiono yang menunjukkan bahwa pemberian intervensi pendidikan gizi selama 1 bulan ddengan 4 kali pertemuan dapat meningkatkan nilai pengetahuan lebih baik pada kelompok intervensi daripada kelompok kontrol ${ }^{21}$.

Tabel 3 Rerata skor sikap kader pada kelompok intervensi dan kontrol

\begin{tabular}{|c|c|c|c|}
\hline \multirow[t]{2}{*}{ Sikap } & Intervensi & Kontrol & \multirow[t]{2}{*}{$\mathrm{p}$ value } \\
\hline & \multicolumn{2}{|c|}{$\mathrm{n}(\%)$} & \\
\hline Pre-test (rataan $\pm \mathrm{SD})$ & $83.53 \pm 8.11$ & $81.13 \pm 7.49$ & $0.239^{3}$ \\
\hline Post-test (rataan \pm SD) & $90.26 \pm 6.74$ & $81.4 \pm 7.37$ & $0.001^{3}$ \\
\hline Post-test 2 (rataan \pm SD) & $90.33 \pm 6.47$ & $80.46 \pm 7.6$ & $0.001^{3}$ \\
\hline Selisih (Post-test 1 - Pre-test) & 6.73 & 0.27 & $0.047^{3}$ \\
\hline $\mathrm{p}$ value & $0.002^{4}$ & $0.326^{4}$ & \\
\hline $\begin{array}{l}\text { Selisih (Post-test } 2 \text { - Post test } 1) \\
\text { p value }\end{array}$ & $\begin{array}{c}0.07 \\
0.573^{4}\end{array}$ & $\begin{array}{l}-0.94 \\
0.004^{4}\end{array}$ & $0.012^{3}$ \\
\hline
\end{tabular}

Hasil pre-test pada Tabel 3 menunjukkan bahwa tidak terdapat perbedaan yang signifikan rerata sikap kader antara kelompok intervensi dan kontrol ( $p>0.05)$. Hasil setelah intervensi (post-test 1) dan sebulan setelah intervensi (post-test 2) menunjukkan terdapat perbedaan yang signifikan sikap antara kedua kelompok $(p<0.05)$. Hasil penelitian ini sejalan dengan penelitian Jumiyati et al tahun 2014 bahwa pemberian intervensi pendidikan gizi pada kader dapat meningkatkan peningkatan sikap tentang gizi pada kelompok intervensi dibandingkan kelompok kontrol 22 .

Berdasarkan selisih nilai sikap positif kader antara sebelum dan setelah intervensi diketahui bahwa pendidikan gizi dapat meningkatkan sikap positif kader yang signifikan pada kelompok intervensi $(p<0.05)$.
Sedangkan pada kelompok control, sikap positif kader meningkat namun tidak signifikan $(p>0.05)$. Selain itu, nilai sikap positif saat post-test 2 pada kelompok intervensi relatif meningkat namun tidak signifikan dan pada kelompok kontrol mengalami penurunan yang signifikan. Hasil ini mengindikasikan bahwa peningkatan yang tidak signifikan pada kelompok intervensi disebabkan karena saat post-test 1 sebagian besar rataan

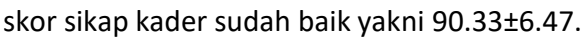

Sikap merupakan perkembangan dari pengetahuan (predisposisi) untuk bertindak atau berperilaku23. Dampak positif dari proses belajar adalah terjadinya perubahan ke ranah afektif yaitu menciptakan kesadaran dan adanya peningkatan sikap positif terhadap apa yang telah diajarkan ${ }^{22}$. 
Tabel 4 Sebaran data kader berdasarkan indikator benar melakukan konseling di posyandu

\begin{tabular}{|c|c|c|c|c|c|c|}
\hline \multirow[b]{2}{*}{ Indikator } & \multicolumn{2}{|c|}{ Pre } & \multicolumn{2}{|c|}{ Post-1 } & \multicolumn{2}{|c|}{ Post-2 } \\
\hline & 1 & $\underline{\mathrm{K}}$ & 1 & $\underline{\mathrm{K}}$ & 1 & $\underline{K}$ \\
\hline & & & \multicolumn{2}{|c|}{$\mathrm{n}(\%)$} & & \\
\hline \multicolumn{7}{|l|}{ Kemampuan bertanya } \\
\hline 1. Menanyakan kabar ibu dan & 30 & 30 & 30 & 30 & 30 & 30 \\
\hline balitanya & $(100.0)$ & $(100.0)$ & $(100.0)$ & $(100.0)$ & $(100.0)$ & $(100.0)$ \\
\hline 2. Berat badan bulan lalu & $16(53.3)$ & $16(53.3)$ & 19(63.3) & $20(66.7)$ & $21(70.0)$ & $20(66.7)$ \\
\hline 3. Masih diberikan ASI atau tidak & $11(36.7)$ & $9(30.0)$ & $13(43.3)$ & $10(33.3)$ & $13(43.3)$ & $9(30.0)$ \\
\hline $\begin{array}{l}\text { 4. Anak pernah sakit sebulan } \\
\text { terakhir }\end{array}$ & $0(0)$ & $0(0)$ & $21(70.0)$ & $8(26.7)$ & $21(70.0)$ & $8(26.7)$ \\
\hline 5. Nafsu makan/makanan harian & 0 & 0 & 23 & 15 & 23 & 14 \\
\hline anak & (0) & (0) & $(76.7)$ & $(50.0)$ & (76.7) & $(46.7)$ \\
\hline \multicolumn{7}{|l|}{ Kemampuan menganalisa } \\
\hline 6. Hasil penimbangan dengan KMS & $11(53.3)$ & $14(46.7)$ & 73.3 & $14(46.7)$ & $22(73.3)$ & $15(50.0)$ \\
\hline 7. Penyebab berat badan balita & 14 & 14 & 19 & 15 & 19 & 16 \\
\hline menurun & $(46.7)$ & $(46.7)$ & $(63.3)$ & $(50.0)$ & $(63.3)$ & $(53.3)$ \\
\hline \multicolumn{7}{|l|}{ Kemampuan bertindak } \\
\hline 8. Membantu memecahkan & 30 & 30 & 30 & 30 & 30 & 30 \\
\hline masalah & $(100.0)$ & $(100.0)$ & $(100.0)$ & $(100.0)$ & $(100.0)$ & $(100.0)$ \\
\hline 9. Memberikan informasi gizi yang & 12 & 13 & 21 & 13 & 19 & 13 \\
\hline relevan dengan masalah & $(40.0)$ & $(43.3)$ & $(70.0)$ & $(43.3)$ & $(63.3)$ & $(43.3)$ \\
\hline \multicolumn{7}{|l|}{ Kemampuan berkomunikasi } \\
\hline 10. Menghindari kata/kalimat yang & 10 & 10 & 15 & 10 & 16 & 9 \\
\hline menghakimi & $(33.3)$ & $(33.3)$ & $(50.0)$ & $(33.3)$ & (53.3) & $(30.0)$ \\
\hline 11. Memuji ibu balita telah membawa & 30 & 30 & 30 & 30 & 30 & 30 \\
\hline anaknya ke posyandu & $(100.0)$ & $(100.0)$ & $(100.0)$ & $(100.0)$ & $(100.0)$ & $(100.0)$ \\
\hline 12. Memberikan motivasi kepada ibu & 18 & 18 & 23 & 15 & 23 & 15 \\
\hline agar berat badan anak meningkat & $(60)$ & (60) & $(76.7)$ & $(50.0)$ & (76.7) & $(50,0)$ \\
\hline
\end{tabular}

I=kelompok Intervensi, K=Kelompok control

Keterampilan yang dinilai pada Tabel 4 adalah kemampuan konseling gizi yang dilakukan kader pada meja 4 di saat posyandu. Kemampuan konseling gizi diukur berdasarkan 4 indikator yaitu kemampuan bertanya, menganalisa, bertindak dan berkomunikasi. Hasil pre-test menunjukkan sebagian besar kader belum terampil dalam melakukan konseling gizi. Penilaian indikator yang belum benar dilakukan (kurang dari 50\%) adalah tidak menanyakan masih diberikan ASI atau tidak, apakah anak pernah sakit sebulan terakhir dan bagaimana makanan harian anak, menganalisa penyebab berat badan menurun, memberikan informasi gizi yang relevan dengan masalah serta menghindari kalimat yang menghakimi.
Hasil pre-test ini dapat diindikasikan karena sebagian besar kader belum pernah melakukan konseling di posyandu. Selama ini kader hanya sekedar menyampaikan informasi ketika ibu balita bertanya kepada kader terkait kondisi balitanya, selebihnya konseling dilakukan oleh tenaga kesehatan puskesmas yang hadir setiap hari $\mathrm{H}$ posyandu. Hasil post-test menunjukkan pendidikan gizi dapat meningkatkan keterampilan konseling gizi secara signifikan pada kelompok intervensi yang relatif lebih tinggi dibandingkan kelompok kontrol. Semenatara hasil post-test 2 tidak terdaapat perbedaan dengan hasil post-test 1 .

Tabel 5 Rerata skor keterampilan konseling kader pada kelompok intervensi dan kontrol

\begin{tabular}{lccc}
\multicolumn{2}{c}{ Kabel 5 Rerata skor keterampilan konseling kader pada kelompok intervensi dan kontrol } \\
\cline { 2 - 3 } (Konseling gizi) & Intervensi & p value \\
\cline { 2 - 3 } Pre-test (rataan \pm SD) & \multicolumn{2}{c}{$\mathrm{n}(\%)$} & \\
\hline Post-test (rataan \pm SD) & $51.94 \pm 13.78$ & $51.11 \pm 14.13$ & $0.818^{1}$ \\
Post-test 2 (rataan \pm SD) & $73.88 \pm 18.66$ & $58.33 \pm 13.13$ & $0.001^{1}$ \\
Selisih (Post-test 1 - Pre-test) & $74.17 \pm 18.48$ & $58.05 \pm 13.39$ & $0.001^{1}$ \\
p value & 21.94 & 7.22 & $0.001^{1}$ \\
Selisih (Post-test 2 - Post test 1) & $0.001^{2}$ & $0.006^{2}$ & \\
p value & 0.29 & -0.28 & $0.556^{1}$ \\
\hline
\end{tabular}

1Uji Mann Whitney, signifikan bila $p<0.05$

${ }^{2}$ Uji Wilcoxon, signifikan bila $p<0.05$

Tabel 5 menunjukan bahwa tidak ada perbedaan yang signifikan nilai keterampilan kelompok intervensi dan kontrol ( $p>0.05)$. Kemudian hasil post-test 1 dan post-test 2 menunjukkan terdapat perbedaan yang signifikan antar kedua kelompok $(p<0.05)$. Hasil penelitian ini sejalan dengan penelitian Jumiyati et al di Bengkulu yang menunjukkan terjadi peningkatan praktik konseling kader setelah diberikan pelatihan kader dengan modul22. 
Hasil penelitian lainnya Rahmawati et al di Bogor yang menunjukkan bahwa terdapat peningkatan pengetahuan, sikap dan keterampilan konseling gizi kader yang diberikan pendidikan gizi tentang pemberian makan bayi dan anak (PMBA) ${ }^{8}$.

Berdasarkan selisih nilai keterampilan konseling gizi antara sebelum dan setelah intervensi diketahui bahwa pendidikan gizi dapat meningkatkan nilai keterampilan konseling gizi secara signifikan pada kelompok intervensi sebesar 21.94 poin relatif lebih tinggi daripada kelompok kontrol yakni 7.22 poin Sementara itu, sebulan setelah intervensi (post-test 2), nilai keterampilan konseling pada kelompok intervensi mengalami peningkatan namun tidak berbeda signifikan. Sedangkan, kelompok kontrol mengalami penurunan namun tidak berbeda signifikan.

Kombinasi teknik pendidikan gizi dengan simulasi dan praktek dan media pendukung seperti modul terbukti efektif meningkatkan pengetahuan dan keterampilan kader ${ }^{24}$. Pendididikan gizi diberikan bertujuan untuk memperbaiki penguasaan keterampilan dan teknik pelaksanaan kerja kader agar terinci dan rutin, sehingga kesenjangan kecakapan kader dalam melaksanakan tugasnya seperti melakukan konseling dapat teratasi ${ }^{18}$.

\section{KESIMPULAN}

Pemberian pendidikan gizi dapat mempengaruhi peningkatan skor pengetahuan, sikap dan keterampilan kader. Namun yang paling mempengaruhi di antara tiga variabel tersebut adalah skor pengetahuan. Saran yang bisa diberikan adalah pemberian pendidikan gizi dengan metode simulasi dan praktik dilakukan secara rutin dan berkelanjutan. Hal ini bertujuan agar pengetahuan dan keterampilan kader terus meningkat dan terjaga. Hasil penelitian ini dapat digunakan sebagai bahan rujukan bagi peneliti lainnya serta pemerintah yang bertanggungjawab terhadap kader posyandu dalam meningkatkan pengetahuan, sikap dan keterampilan konseling kader melalui pendidikan gizi dengan menggunakan metode simulasi dan praktik.

\section{ACKNOWLEDGEMENT}

Peneliti mengucapkan terima kasih kepada Dinas Kesehatan Kota Palu, Puskesmas Nosarara dan Sangurara dan kader-kader Posyandu di Kecamatan Tatanga Kota Palu, serta semua pihak yang telah membantu penelitian ini.

\section{REFERENSI}

1. Kementerian Desa Pembangunan Daerah Tertinggal dan Transmigrasi. Buku saku desa dalam penanganan stunting. Buku Saku Desa Dalam Penanganan Stunting (2017).

2. Kemenkes RI. RISKESDAS 2018. (Badan Penelitian dan Pengembangan Kesehatan, 2018).

3. Kemenkes RI. Hasil Pemantauan Status Gizi ( PSG ) TAHUN 2017. (Direktorat Gizi Masyarakat, 2018).

4. Kemenkes RI. Situasi Balita Pendek. Infodatin Pusat Data dan Informasi Kemenkes RI (2016).

5. Promkes Kemenkes RI. Ayo ke Posyandu Setiap
Bulan. Transfusion Medicine and Hemotherapy (2012). doi:10.1159/000317898.

6. Rhapsodia, NA Andari, Sri Sumarmi, S. Hubungan Keaktifan Kader dan Partisipasi lbu pada Kegiatan Posyandu dengan Cakupan ASI Eksklusif di Wilayah Kerja Puskesmas Waru Sidoarjo Relationship between Cadres A ctivity \& Mother ' s Participation to Posyandu Activity with Exclusive Breastfeeding Co. Amerta Nutr 3, 9499 (2019).

7. Ibnu Hasyim, Umi Romayati Keswara, Ricko Gunawan, R. Faktor-Faktor Yang Berhubungan Dengan Kinerja Kader Posyandu Di Wilayah Kerja Upt Puskesmas Tanjung Bintang Kabupaten Lampung Selatan. 9, 51-58 (2015).

8. Rahmawati, S. M., Madanijah, S., Anwar, F. \& Kolopaking, R. The effectiveness education of counseling of infant and young child feeding as intensive to improve counseling performance of Posyandu cadres in Bogor, Indonesia. Int. J. Community Med. Public Heal. 6, 2280-2288 (2019).

9. Rostinah, Widajanti, L. \& Kartika Wulan, L. R. Evaluasi Manajemen Pelatihan Kader Pos Pelayanan Terpadu ( Posyandu) di Puskesmas Paruga Kota Bima Provinsi Nusa Tenggara Barat Evaluation on Integrated Health Post Cadres Training Management in Paruga Primary Healthcare Centers at Bima City Nusa Tenggar. J. Manaj. Kesehat. Indones. 03, 212-221 (2015).

10. Isra, W. O. A., Suryawati, C. \& Kartini, A. Evaluasi Pelaksanaan Revitalisasi Posyandu dalam Penurunan Prevalensi Balita Gizi Buruk di Kota Baubau Provinsi Sulawesi Tenggara Evaluation on the Implementation of Integrated Health Service Post in Decreasing Underfive Protein Energy Malnutrition Cases. J. Manaj. Kesehat. Indones. 02, 232-241 (2014).

11. Contento, I. R. Nutrition education: Linking theory and practice. (Jones \& Bartlett Publishers, 2011).

12. Sharma Manoj and Romas John A. Theoretical Foundations of Health Education and Health Promotion.

13. Gyawali, B. et al. Diabetes management training for female community health volunteers in Western Nepal : an implementation experience. 1-10 (2018)

14. Kemenkes RI. Buku Kesehatan Ibu dan Anak. (Kementerian Kesehatan dan JICA, 2016).

15. Wahyutomo, A. H. Tumbuh Kembang Balita di Puskesmas Kalitidu-Bojonegor. (Universitas Sebelas Maret, 2010).

16. Legi, N. N., Rumagit, F., Montol, A. B. \& Lule, R. Faktor Yang Berhubungan Dengan Keaktifan Kader Posyandu Di Wilayah Kerja Puskesmas Ranotana Weru. Gizido 7, 429-436 (2015).

17. Simanjuntak, M. Karakteristik Sosial Demografi dan Faktor Pendorong Peningkatan Kinerja Kader Posyandu. J. Penyul. 10, 49-58 (2017).

18. Alfina, R. \& Isfandiari, M. A. Faktor yang Berhubungan Dengan Peran Aktif Kader Dalam Penjaringan Kasus Probable Difteri. J. Berk. 
Epidemiol. 3, 353-365 (2015).

19. Hardiyanti, R., Jus'at, I. \& Angkasa, D. Hubungan lama kerja menjadi kader, pengetahuan, pendidikan, pelatihan dengan presisi dan akurasi hasil penimbangan berat badan balita oleh kader Posyandu. AcTion Aceh Nutr. J. 3, 74 (2018).

20. Rahmawati, S. M. Efektivitas Model Edukasi Konseling Pemberian Makan Bayi dan Anak Intensif (KPMBA-I) dalam Meningkatkan Kinerja Konseling Kader Posyandu. (Institut Pertanian Bogor, 2019).

21. Anani DF \& Mahmudiono Trias. Pengaruh Pendidikan Gizi Terhadap Pengetahuan, Sikap Dan Perilaku Konsumsi Pangan Isoflavon Pada Mahasiswi Pre-Menstrual Syndrome Effect of Nutrition Education on Knowledge , Attitude and Behavior in Consuming Isoflavones Rich Food among Female Students. Amerta Nutr 2, 136146 (2018).

22. Jumiyati, Nugrahaeni, SA, Margawati, A. Pengaruh Modul Terhadap Peningkatan Pengetahuan, Sikap Dan Praktek Kader Dalam Upaya Pemberian Asi Eksklusif. Gizi Indon 37, 1928 (2014).

23. Merita. Keberlanjutan dampak penyuluhan gizi terhadap perilaku gizi ibu dan kualitas pelayanan posyandu merita. (Institut Pertanian Bogor, 2013).

24. Hastuti, S. \& Sembiring, I. Effect of Empowerment of Cadres by Using Module for Changes in Nutritional Behavior in Pregnant Women in Dlingo, Bantul, Indonesia. in The 5th AASIC 2017 60-65 (Khon Kaen University, 2017). 